\title{
KERJA SAMA AMERIKA SERIKAT DAN RUSIA DI ANGKASA LUAR: PERSPEKTIF RUSIA
}

\author{
Ajeng Novia Anggraini \\ Universitas Indonesia \\ Email: anggrainiajeng101@gmail.com
}

\begin{abstract}
This paper analyzes the U.S.-Russia cooperation of space security as two superpowers in the form of the ISS program. Most of the previous articles on this topic only explained the background of the ISS project and the process of Russia joining this project. U.S and Rusia have a "high intention" relationship during the Cold War. Even today the United States and Russia are still at odds with many things. This article uses theory of international cooperation that can explain the reasons behind Russia joint the ISS project carried out by the United States. This article shows that the reasons behind Russia's joining the ISS program are more practical than idealistic considering that Russia has interests that must be fulfilled since the country is the successor to the Soviet space project.
\end{abstract}

Key Words: United States, Russia, Space Cooperation, ISS, International Cooperation

\section{PENDAHULUAN}

Berakhirnya Perang Dunia II merupakan titik awal memburuknya hubungan antara Amerika Serikat dan Uni Soviet (yang kini menjadi Rusia). Pasca Perang Dunia II ini muncul konflik baru yang disebut dengan Cold War atau Perang Dingin antara Uni Soviet dan Amerika Serikat di mana kedua negara sama-sama menyebarluaskan ideologinya ke berbagai penjuru dunia. Sistem perang yang dilakukan oleh kedua negara adidaya ini dalam menyebarkan ideologinya disebut dengan Proxy War di mana Uni Soviet meyebarkan paham komunisnya dan Amerika Serikat dengan paham liberalnya. Hal ini memicu terbentuknya dua blok yaitu blok barat yang dipimpin oleh Amerika Serikat dan blok timur yang dipimpin oleh Uni Soviet.

Selama masa Perang Dingin (1947-1991) hubungan Amerika Serikat dan Uni Soviet semakin memanas. Kedua negara semakin menginginkan kekuasaan penuh di dalam sistem Internasional. Salah satu tindakan yang dilakukan adalah dengan melakukan produksi senjata nuklir dalam jumlah besar yang pada akhirnya menggiring kedua negara menuju era perlombaan senjata (Arms Race). Perlombaan senjata ini membuat sistem Internasional mendesak kedua negara untuk melakukan perjanjian pengurangan persenjataan strategis atau START (Strategic Arms Reduction Treaty) pada tahun 1982 dikarenakan perlombaan senjata yang terjadi dianggap memunculkan ketegangan yang dapat mengancam perdamaian internasional. 
Hari disaat manusia pertama kali menginjakkan kakinya di luar angkasa merupakan hari di mana angkasa luar menjadi subjek bagi politik internasional. Sputnik I merupakan satelit buatan pertama yang dibuat di muka bumi dan merupakan satelit yang dibuat dan diproduksi oleh Uni Soviet pada tanggal 4 Oktober 1957. Keberadaan satelit ini memunculkan kekhawatiran bagi Amerika Serikat terkait keamanan negerinya terhadap misil yang dimiliki Uni Soviet. Amerika Serikat mulai serius menanggapi kemampuan teknologi Rusia. Sputnik tidak hanya menimbulkan Space Race, namun juga menimbulkan perlombaan senjata dan memperkeruh suasana Perang Dingin di antara dua negara adidaya tersebut (Everett, 2002).

Sputnik hanyalah sebuah satelit sederhana yang menggunakan batu baterai sebagai tenaga pembangkitnya dan memiliki kemampuan untuk mengirimkan sinyal radio disertai empat transmeter yang berbentuk seperti bola berukuran besar. Saat ini ada ribuan satelit yang beredar mengelilingi bumi. Satelit-satelit ini memuat data gambaran bumi secara keseluruhan, data telekomunikasi, hingga navigasi dari berbagai macam data ilmiah. Beberapa memiliki ukuran sekepal tangan dan sebagian lainnya memiliki ukuran yang lebih besar dari bus. Salah satu satelit paling besar yang ukurannya hampir sama dengan sebuah rumah, diberi nama International Space Station (ISS). ISS merupakan proyek internasional yang diprakarsai oleh space faring states $^{1}$ dan seringkali dipandang sebagai bentuk kerja sama manusia di luar angkasa.

ISS awalnya direncanakan sebagai sebuah "Stasiun Angkasa Freedom" NASA dan dipromosikan oleh Presiden Reagan, namun diketahui terlalu mahal. Setelah berakhirnya Perang Dingin, proyek ini diadakan kembali sebagai proyek gabungan NASA dan Rosaviakosmos Russia. Pada 1 Desember 1987, NASA mengumumkan empat nama perusahaan AS yang akan diberikan kontrak sebagai penyedia komponen yang akan digunakan oleh Amerika Serikat untuk Stasiun Angkasa: Boeing Aerospace, Astro-Space Division General Electric, McDonnell Douglas, dan Rocketdyne Division Rockwell. ISS merupakan proyek gabungan dari 16 negara: Amerika Serikat, Rusia, Jepang, Kanada, Brasil dan 11 negara dari Uni Eropa. Agensi luar angkasa yang terlibat adalah NASA Amerika Serikat, Russian Federal Space Agency, Japan Aerospace Exploration Agency (JAXA), Canadian Space Agency (CSA/ASC), Brazilian Space Agency (Agência Espacial Brasileira)

\footnotetext{
${ }^{1}$ Space faring states merupakan negara-negara yang berperan aktif berkegiatan di luar angkasa baik dalam space travel maupun space transport serta memiliki spacecraft maupun spaceplane.
} 
(AEB) dan European Space Agency (ESA). Menurut konfigurasi pada 2003, stasiun ini memiliki massa $187.016 \mathrm{~kg}$, memiliki tempat hidup $425 \mathrm{~m}^{3}$ serta berukuran panjang $73 \mathrm{~m}$, lebar 52m, dan tinggi 27,5 m. Eksplorasi ruang angkasa yang dilakukan dalam program ISS ini setidaknya telah melibatkan 16 Space Shuttle Amerika dan 22 Rusia. Penerbangan yang dilakukan oleh Rusia, 8 diantaranya berawak dan 14 tidak berawak. Konstruksi stasiun ini membutuhkan 51 kali perjalanan ke angkasa, 25 di antaranya menggunakan space shuttle milik Amerika Serikat dan 26 lainnya menggunakan milik Rusia dengan total jumlah waktu yang dihabiskan di stasiun mencapai 318 jam, 37 menit.

Negara-negara yang paling banyak memberikan kontribusi terhadap program ISS adalah Rusia dan Amerika Serikat. Kedua negara tersebut memiliki peranan paling krusial dalam pembangunan pangkalan dan juga menyuntikkan dana terbesar serta memastikan program tersebut tetap berjalan (Sadeh \& Lester, 1996). Meskipun adanya ketegangan yang terjadi di antara kedua negara tersebut, Amerika Serikat dan Rusia tetap bekerja sama dalam mendukung keberlangsungan program ISS. Bahkan Amerika Serikat saat ini masih bergantung kepada Rusia guna menerbangkan astronot-astronotnya ke luar angkasa pasca diberhentikannya Space Shuttle miliknya di tahun 2011. Hal ini menunjukkan anomali dalam hubungan kedua negara: Amerika Serikat dan Uni Soviet pasca Perang Dunia II cenderung didominasi oleh persaingan yang ketat, namun pada tahun 1998 ketika jatuhnya pemerintahan Uni Soviet. Ketika Uni Soviet terpecah menjadi 15 negara bagian, saat itu teknologi ruang angkasanya juga terpecah dan diwariskan kepada masing-masing negara bagiannya. Kala itu Amerika Serikat tertarik untuk mengajak Rusia bergabung dan berkerja sama pada program ISS.

Kajian terdahulu yang membahas mengenai hubungan kerja sama luar angkasa Uni Soviet dan Amerika Serikat sebagian besar melihat hubungan kerja sama kedua negara ini dari beberapa perspektif antara lain; (1) bidang ekonomi, (2) bidang politik dan keamanan, serta (3) transfer teknologi. Sudut pandang yang pertama dilihat dari faktor ekonomi yang mendorong kedua negara melakukan kerja sama. Tulisan Savelyev (2004) menjelaskan bahwa Rusia mengalami kesulitan secara finansial dalam mendanai proyek luar angkasanya setelah presentasi dana untuk industrinya turun dari total $0,73 \%$ dari total GDP pada tahun 1989 menjadi 0,12\% dari total GDP di tahun 2001, oleh sebab itu kerja sama internasional membuat Russia mendapatkan kesempatan untuk mendanai proyek luar angkasanya. Lebih lanjut, Launius (2009) menjelaskan bahwa proyek kerja sama ini memperluas investasi yang 
dilakukan oleh Amerika Serikat. Proyek kerja sama antara Amerika Serikat dan Rusia ini juga dapat meningkatkan keseimbangan perdagangan (balance of trade) dengan menciptakan pasar baru bagi produk-produk kedirgantaraan Amerika Serikat (Shaffer \& Shaffer, 1980, p. 17).

Sudut pandang yang kedua melihat kerja sama Amerika Serikat dan Rusia dari segi politik-keamanan. Dari sudut pandang para pemimpin Amerika Serikat, setiap adanya pendaratan di bulan maka setiap kemitraan internasional akan membawa legitimasi yang lebih besar untuk keseluruhan proyek (Launius, 2009). Perjanjian dengan negara asing juga membantu Amerika Serikat untuk mengisolasi proyek luar angkasanya dari perubahan anggaran dan perubahan politik karena sifat dasar dari politik Amerika Serikat. Oleh sebab itu kerja sama internasional dapat membantu menstabilkan beberapa polemik dalam proyek luar angkasa yang ada dan menjadi benteng pada permaslaahan domestik Amerika Serikat (Logsdon, 1991).

Tulisan sebelumnya dari sudut pandang keamanan menjelaskan bahwa Amerika Serikat dan Rusia memiliki kesepakatan untuk mengatasi suatu ancaman. Diawali dari kesepakatan antara Presiden Amerika Serikat, George W. Bush dan Presiden Rusia, Vladimir Putin, yang melihat pentingnya kerja sama di bidang keamanan terkait isu nuklir (Luongo, 2001). Setelah peristiwa 9/11, Amerika Serikat dan Rusia sepakat untuk meningkatkan kerja sama terkait keamanan global, termasuk akibat dari adanya ancaman terorisme (Brooks, 2009) dan ancaman transnasional nuklir oleh Korea Utara dan Iran (Oliker, Crane, Schwartz, \& Yusupov, 2009). Lebih lanjut, tulisan Katz (2014) menjelaskan adanya common interest antara Amerika Serikat dan Rusia terkait penanganan ancaman Al-Qaeda dan Taliban. Wilkening (2012) menunjukkan bahwa hubungan Amerika Serikat dan Rusia ini menghasilkan keuntungan keamanan bagi masing-masing negara, meningkatkan stabilitas keamanan, dan mendorong kerja sama industri.

Transfer teknologi juga merupakan faktor yang banyak dibahas dalam kajian terdahulu terkait kerja sama luar angkasa Uni Soviet dan Amerika Serikat. Bagi Amerika Serikat kerja sama ini dapat meningkatkan pemahaman yang tinggi dalam bidang luar angkasa dalam waktu yang lebih singkat (Shaffer \& Shaffer, 1980). Kerja sama ini juga dapat membantu Amerika Serikat dalam pengembangan eksperimen komplementer namun dalam beragam jenis eksperimen dari para ilmuwan internasional (Logsdon, 1991).

Ketiga kategori kajian terdahulu tersebut telah menunjukkan apa saja alasan dibalik terjadinya hubungan kerja sama antara Rusia dan Amerika Serikat di luar angkasa baik dari 
aspek ekonomi, politik, keamanan, dan transfer teknologi. Meskipun begitu, kejanggalan yang terjadi dalam hubungan Rusia dan Amerika Serikat ini terletak pada keputusan Rusia yang pada akhirnya bergabung dalam proyek ISS sesaat setelah berakhirnya perang dingin. Oleh sebab itu, tulisan ini dimaksudkan untuk menjawab pertanyaan penelitian, "Mengapa Rusia memutuskan bergabung dalam program ISS sesaat setelah runtuhnya Uni Soviet?” Untuk menjawab pertanyaan tersebut, tulisan ini menjelaskan operasionalisasi dari teori kerja sama internasional dalam hubungan kerja sama Amerika Serikat-Rusia di luar angkasa. Di bagian berikutnya, secara berurutan tulisan ini menjelaskan mengenai teori kerja sama internasional, pembahasan yang berisi analisa alasan kerja sama Amerika Serikat-Rusia dari sudut pandang teori kerja sama internasional, dan bagian penutup.

\section{KERANGKA ANALISIS}

\section{Teori Kerja Sama Internasional}

Asumsi dasar mengenai kerja sama internasional di antaranya adalah pertama bahwa sistem internasional bersifat anarki yang artinya tidak ada kekuatan yang dominan dalam sistem internasional (Milner, 1991; Powell, 1994). Pada sistem internasional yang bersifat anarki membuat negara berusaha untuk mencapai tujuan utamanya berupa keamanan. Keamanan ini akan tercapai apabila negara berhasil melindungi kepentingannya. Dengan adanya kerja sama antar Great Powers, maka terciptalah sebuah tatanan dunia anarki yang relative damai. Kedua, kerja sama internasional berfokus kepada negara sebagai aktor utamanya sementara aktor non-negara dan politik domestik diragukan kepentingannya dalam kerja sama internasional. Ketiga, kerja sama internasional mengasumsikan negara bersifat rasional dan konsisten dalam mencapai targetnya. Pada awalnya kerja sama internasional di masa awal fokus kepada sifat negara yang egois dan cenderung menilai segalanya dari segi materi seperti keamanan nasional dan kemakmuran meskipun pendekatan seperti ini dapat mencakup pemikiran lainnya yang telah dipertimbangkan (Elster, 1984; Ferejohn, 1991) contohnya HAM dan keadilan.

Kerja sama didukung oleh adanya kemungkinan terjadinya hubungan timbal balik (resiprokalitas). Resiprokalitas yang dimaksud adalah sebuah negara akan mau melakukan kerja sama ketika dibutuhkan apabila negara lainnya juga mau melakukan hal yang sama di masa depan. Apabila kedua negara yang bekerja sama mampu melaksanakan komitmen ini maka kemungkinan adanya salah satu aktor yang melakukan pembelotan dapat diatasi. Hal ini membuat resiprokalitas menjadi salah satu faktor yang dapat mendukung terjadinya kerja 
sama menurut beberapa ahli (Goldstein, 1991; Ward \& Rajmaira, 1992; Goldstein \& Pevehouse, 1997).

Kerja sama juga didukung dengan adanya reputasi. Menurut Kreps (1990) kemungkinan sebuah negara untuk membelot dalam sebuah kerja sama haruslah dapat diamati dengan mudah. Jika tidak, maka sebuah kerja sama itu membutuhkan institusi yang dapat memberikan informasi terkait hal tersebut. Institusi ini didefinisikan sebagai organisasi yang dapat membantu pemantauan secara berkala dan memberikan informasi (Greif et al, 1994; Calvert, 1995). Mercer (1996) berpendapat bahwa meskipun negara sangat sensitif terhadap reputasinya, namun negara lain akan tetap menilai perilaku negaranya berdasarkan perilaku negara tersebut di masa lalu. Reputasi dapat mempengaruhi hasil dari kerja sama melalui rasa saling percaya, apakah seorang aktor dapat dipercaya untuk melakukan hubungan resiprokal di masa depan. Politik domestik merupakan salah satu faktor yang memunjukkan kredibilitas sebuah negara dan mampu menaikkan pamor serta reputasi sebuah negara (Fearon, 1994). Pemimpin negara dapat mengevaluasi seberapa jauh komitmen negara lain dalam pembentukan kerja sama tidak hanya dengan melihat dari bagaimana sebuah negara menunjukkan citra dirinya di dunia internasional namun juga bergantung pada kesan pribadi yang timbul ketika mereka bertemu satu sama lain (Hall \& Yarhi, 2012).

Pada akhirnya implementasi kerja sama internasional dapat berhasil ketika kedua negara dapat menjunjung tinggi nilai resiprokalitasnya dalam kerja sama di masa yang akan datang. Ketika negara dirasa akan memberikan komitmen yang sama di awal kerja sama maka kecil kemungkinan negara tersebut akan membelot dan ingkar terhadap komitmen awalnya. Kapabilitas negara untuk melakukan komitmen ini dapat dilihat dari reputasi negara. Reputasi negara bisa ditinjau melalui perilaku negara di masa lalu dan juga perilaku pemimpin negaranya.

\section{METODE PENELITIAN}

Untuk menjawab pertanyaan penelitian di atas, tulisan ini menggunakan metode penelitian kualitatif dengan data yang bersumber dari data primer dan sekunder. Penulis mengumpulkan data penelitian dalam kurun waktu 15 tahun, mulai dari awal tahun 1980 di tengah masa Perang Dingin yang menjadi titik awal bentuk kerja sama luar angkasa antara Uni Soviet dan Amerika Serikat diinisiasi hingga tahun 1995 ketika Uni Soviet sudah digantikan oleh Rusia dalam proyek luar angkasanya dan bergabung dengan International Space Station (ISS). Data tersebut dikumpulkan dengan melakukan studi pustaka dan 
penelusuruan berita, khususnya dari media daring. Setelah data itu berhasil dikumpulkan, penulis melakukan triangulasi untuk menguji keabsahan data. Triangulasi tersebut dilakukan dengan cara memeriksa akurasi (validitas) dan konsistensi (realibilitas) data penelitian melalui perbandingan sumber-sumber data dan menyesuaikannya dengan pertanyaan penelitian.

\section{PEMBAHASAN}

\section{Citra Proyek Luar Angkasa Rusia}

Pada bulan Desember tahun 1991, Republik Rakyat Sosialis Uni Soviet mengalami keruntuhan. Dari 15 negara bagiannya, tiga negara Slavia (Rusia, Ukraina, dan Belarus) bergabung denga Persemakmuran Negara Merdeka atau yang biasa disebut Commonwealth of Independent States (CIS) pada tanggal 8 Desember di tahun yang sama. Pada saat itu untuk tetap menjaga dan memelihara proyek luar angkasa milik Uni Soviet sebelumnya, Rusia mengambil alih proyek tersebut dengan mendirikan program luar angkasa milik CIS. ${ }^{2}$ Semenjak saat itu Rusia menjadi negara yang paling dominan dalam keberlangsungan program luar angkasa setelah keruntuhan Uni Soviet.

Setelah keruntuhan Uni Soviet, Rusia mengemban tugas untuk kembali membangun pemerintahannya yang baru setelah aspek ekonomi dan politiknya terisolasi, dan membuat Rusia menjadi kompetitif untuk bersaing dengan pasar Barat kembali. Politbiro dan Sekretariat Partai Komunis tidak lagi menjadi pengambil keputusan utama di Rusia. Duma yang baru saja dibentuk, atau dewan legislatif, mengontrol proses pengalokasian, sementara kementerian eksekutif tunduk pada perdana menteri yang telah ditunjuk oleh presiden. Sebagai konsekuensinya, program luar angkasa Rusia mengalami kesulitan dalam memperluas jaringannya guna memfasilitasi dirinya sebagai negara yang kini telah merdeka. Dahulu, negara-negara selain Rusia, yang menjadi bagian dari Uni Soviet, bebas untuk menggunakan fasilitas yang ada di Moskow seperti biro desain, pabrik, fasilitas peluncuran (cosmodrome), dan banyak situs yang digunakan untuk telemetri satelit dan pelacakan. Sekarang, negara-negara yang sudah merdeka dari Uni Soviet diwajibkan untuk membayar

\footnotetext{
${ }^{2}$ The “Minsk Space Agreement," yang ditandatangani 30 Desember 1991, oleh perwakilan republik Azerbaijan, Armenia, Belarus, Kazakhstan, Kyrgyzstan, Tajikistan, Turkmenistan, Uzbekistan, dan Federasi Rusia, menjabarkan pedoman umum untuk melanjutkan program luar angkasa milik Uni Soviet melalui penggunaan gabungan sumber daya dan pendanaan yang proporsional. Ukraina menandatangani perjanjian ini pada musim panas 1992. Dokumen itu sendiri disimpan dalam arsip Republik Belarus di ibukota Minsk
} 
fasilitas yang ada di tanah mereka sendiri yang meliputi pelayanan dan juga perangkatperangkat yang ada.

Rusia memiliki hampir seluruh fasilitas yang dapat menunjang keberlangsungan program luar angkasa. Dari segelintir fasilitas yang dimilikinya, hanya Kosmodrom Baikonur $^{3}$ yang merupakan salah satu fasilitas yang akan sulit digantikan oleh Rusia dalam tempo yang singkat. Alih-alih membangun Kosmodrom yang baru, Pemerintah Rusia lebih memilih untuk menyewa Kosmodrom dari Kazakhstan untuk dua puluh tahun ke depan karena dirasa akan jauh lebih murah dan efektif. Angkatan Militer Luar Angkasa Rusia (VKS) dan Badan Antariksa Rusia (RSA) sedang berjuang mengenai penting atau tidaknya membangun kosmodrome baru di situs balistik-rudal tua di Svobodny. VKS menginginkan keamanan meluncurkan semua muatan militer dari tanah Rusia, tetapi RSA tidak ingin pendanaannya dilemahkan karena pengalihan dana dari Baikonur.

RSA didirikan pada tanggal 25 Februari 1992 atas dekrit Presiden Rusia dan diberikan piagam oleh dewan legislatifnya pada 6 Oktober 1993 (Activity, 1993). Isi dari mandat piagam tersebut kurang lebih mengenai pemanfaatan penggunaan kompleks roket antariksa Rusia untuk kepentingan pengembangan sosio-ekonomi Federasi Rusia, keamanan, dan kerja sama internasional (Yeltsin, 1992). Pada tahun 1993 RSA seharusnya didanai oleh anggaran belanja Federasi Rusia hingga tahun 1995, namun pada tahun 1994 Kementerian Sains dan Teknologi Rusia mengambil alih pendanaannya dan membuat sistem ini sangat berbeda pada masa Uni Soviet. Sebelumnya tidak ada satupun instansi yang mau mendanai program angkasa luar dengan sendirinya dan melibatkan pemerintah dalam pembuatan kebijakan di angkasa luar. Kehadiran instansi dan lembaga yang mendanai ini mengubah sistem keberlangsungan program antariksa Rusia dari berbagai aspek.

Dengan adanya pendanaan dari instansi melalui anggaran pribadinya maka kini program antariksa Rusia dapat memisahkan bagian sipil dan militernya. Meskipun pada akhirnya militer akan tetap mendapatkan porsi yang lebih besar dalam proyek ini, namun RSA akhirnya bisa membayar personil sipil untuk mengambil alih pekerjaan yang memang melibatkan masyarakat sipil seperti perawatan dan pengoperasian satelit milik sipil. Pendanaan ini juga membuat fasilitas-fasilitas luar angkasa dapat diakses oleh pihak Barat dikarenakan bagian militer di dalam program sudah dapat dipindahkan sehingga transfer

\footnotetext{
3 Kosmodrom Baykonur (bahasa Rusia: Космодром Байконур, KosmodromBaykonur), juga dipanggil Tyuratam, adalah fasilitas peluncuran luar angkasa tertua dan terbesar yang masih beroperasi di dunia.
} 
teknologi militer yang bersifat sensitif dapat dikontrol serta beberapa instansi pemerintahan juga harus mundur agar lebih kooperatif (Yeltsin, 1992).

RSA terlibat dalam semua fase pengembangan suatu sistem, dari penelitian dan pengembangan hingga tahap produksi. Pada awalnya, agensi yang mendanai tersebut diberi wewenang atas beberapa organisasi penelitian dan produksi termasuk Balai Penelitian Mekanik Sentral dari Bangunan Mesin (TsNIIMash), yang mengoperasikan fasilitas kontrol pesawat ruang angkasa dari Pusat Kendali Penerbangan (TsUP) di Kaliningrad. Setelah perjuangan antara RSA dan beberapa perusahaan ruang yang lebih besar, pemerintah Rusia, dalam dekrit yang ditandatangani oleh Perdana Menteri Chernomyrdin, ${ }^{4}$ memberikan kontrol dari 38 perusahaan kedirgantaraan untuk RSA, yang akan ditambahkan ke empat perusahaan ${ }^{5}$ sudah di bawah kendali RSA.

\section{Rusia dan Stasiun Luar Angkasa Internasional (ISS)}

ISS dilihat sebagai sebuah contoh kerja sama multilateral yang ideal untuk mencapai citra yang lebih bagus di dunia internasional. Namun selayaknya contoh kerja sama yang lain, alasan dibalik kerja sama ini sedikit lebih praktikal dibandingkan idealis. ISS merupakan pangkalan luar angkasa baru milik Amerika Serikat meskipun pangkalan ini dibentuk oleh NASA dan beberapa agensi luar angkasa lainnya. Perjanjian awal mengenai ISS ini menunjukkan bahwa program ini sejak awal memanglah milik Amerika. Pertama, Amerika Serikat lah yang pertama kali membangun dan memelihara stasiun ini termasuk membangun elemen-elemen esensial yang terdapat pada stasiun ini seperti life support dan panel solarnya. Kedua, setiap negara partner ISS bertanggung jawab atas manajemen dan pendanaan setiap penelitiannya dan perangkat-perangkatnya masing-masing (Sadeh \& Lester, 1996). Pada dasarnya ISS dapat menjadi pangkalan luar angkasa Amerika yang ditumpangi oleh beberapa laboratorium milik negara-negara di Eropa dan juga Jepang. Namun yang membuatnya menarik adalah beberapa negara berharap akan mendapatkan otoritas yang sama dan

\footnotetext{
${ }^{4}$ Keputusan tersebut menyatakan, "RSA akan memberikan kontrol negara dan untuk menentukan kebijakan ilmiah, teknis, dan industri negara di bidang perangkat keras roket dan luar angkasa dan untuk memastikan pemenuhan kebijakan tersebut, dan untuk memungkinkan pemenuhan proyek konversi dan reorganisasi struktural dari industri roket dan luar angkasa. "

${ }^{5}$ Empat perusahaan asli di bawah kendali RSA adalah Lembaga Penelitian Ilmiah Bangunan Mesin Kimia (NIIKhimMash), Institut AGAT, Lembaga Penelitian Ilmiah Proses Termal (NIITP), dan Pusat Lembaga Penelitian Ilmiah Bangunan Mesin (TsNIIMash)
} 
mencapai kerja sama multirateral yang efektif semenjak pertama kali diadakannya penandatanganan kontrak dengan ISS. Faktanya, hanya Amerika Serikat yang mampu membangun dan mendanai proyek ini dan menyediakan transportasi bagi negara-negara yang menjadi delegasi guna memberikan power yang lebih terhadap Amerika Serikat (Lynn \& Gibbs, 2003). Namun ketika akhir masa perjanjian ini, yaitu pada tahun 1988, biaya proyek ini terbukti terlalu mahal bagi Kongres Amerika dan NASA pada akhirnya melakukan serangkaian perencanaan ulang guna mengurangi biaya proyek ini (Sadeh \& Lester, 1996, p. 220).

Berakhirnya perang dingin dan runtuhnya Uni Soviet membuat Amerika Serikat perlu mengurangi biaya ISS karena dirasa sudah tidak memiliki musuh lagi, sehingga Amerika akan menstabilkan dunia dikarenakan hanya akan ada satu negara hegemon yang tersisa. Di sisi lain Rusia memiliki pengalaman yang sangat banyak terkait konstruksi dan pemeliharaan pangkalan antariksa serta memiliki infrastruktur dan industri yang dianggap mampu untuk membantu ISS. Partisipasi Rusia dalam program ISS ini juga membantu memperbaiki hubungan Rusia dengan negara-negara Barat pasca perang dingin dan juga menjadi kesempatan negara Barat untuk menunjukkan dukungannya terhadap reformasi politik dan ekonomi Rusia yang akan membantu untuk memperbaiki hubungan ekonomi di antara mantan musuhnya (Sadeh, 2004).

Para ilmuwan Rusia dan industri kedirgantaraan sedang mencari pekerjaan, dan banyak negara berharap untuk mendapatkan teknologi roket Soviet. Jika Rusia mulai bekerja sama dengan ISS, para ilmuwan dan industri ini akan bekerja pada teknologi yang lebih damai yang akan menjadi anugerah, bukan ancaman bagi Barat. Bukan kebetulan bahwa Rusia bergabung dengan Rezim Kontrol Teknologi Rudal (MTCR, sebuah rezim yang bertujuan untuk mengurangi proliferasi teknologi rudal) pada saat yang bersamaan, Rusia juga bergabung dengan program ISS (Whiting, 2003). Pada tahun 1993 AS secara resmi mengundang Rusia ke ISS, dan negosiasi multilateral diselenggarakan di Paris. Awalnya, diharapkan bahwa Rusia akan menjadi anggota penuh dari perjanjian yang dicapai pada tahun 1988 dengan perubahan yang relatif sedikit, karena negara-negara lain ingin mencegah fase panjang negosiasi (Lynn \& Gibbs, 2003). Tetapi dikarenakan ISS harus dirancang ulang, Badan Antariksa Rusia dan Eropa ingin lebih banyak pengaruh untuk menyeimbangkan kontribusi potensial mereka, dan karena perjanjian sebelumnya masih memiliki beberapa masalah yang luar biasa, perjanjian harus dinegosiasikan ulang. 
Beberapa negosiasi bersifat multilateral, tetapi program luar angkasa Rusia dan Amerika juga dibahas dalam pembicaraan bilateral yang berfokus pada aspek politik dan hukum dari perjanjian tersebut. Aspek-aspek ini berpusat di sekitar kontrol stasiun, dan seberapa besar pengaruh Rusia terhadap proses pengambilan keputusan. Alexander Yakovenko adalah pemimpin delegasi Rusia dan menulis artikel tentang negosiasi. Dia menggambarkan pertemuan ini sebagai pertemuan yang dinamis, fleksibel, dan optimis (Yakovenko, 1999). Pada tahun 1994 perjanjian pertama dicapai, memberi Rusia lebih banyak otoritas dan sudah diperbolehkan untuk memberi perintah kepada industri Rusia untuk mulai bekerja pada produk-produk terkait ISS. Meskipun ini menunjukkan kesediaan untuk berkompromi ke Rusia, Amerika Serikat masih tidak mau mengizinkan Rusia untuk bekerja di bagian inti dari stasiun, modul-modul yang berisi dukungan kehidupan dan sistem penting lainnya. NASA bersedia untuk membiarkan Rusia bekerja pada 'komponen jalur kritis', melanggar pedoman yang telah diikuti hingga saat itu, tetapi Rusia akan tetap bergantung pada bagian Amerika dari stasiun dan bukan sebaliknya. Rusia mengusulkan kompromi: mereka akan membangun bagian otonom dari stasiun, secara efektif menciptakan dua inti independen. Tetapi NASA menginginkan program yang terintegrasi dan akhirnya memungkinkan Rusia untuk bekerja di pada pusat stasiun (Sadeh, 2004).

Kesepakatan ISS terakhir yang dicapai pada tahun 1998 memberikan lebih banyak kewenangan kepada negara-negara bagian lain yang berpartisipasi dalam program ini. Amerika Serikat masih menjadi pemimpin proyek dan bertanggung jawab atas keputusan yang berdampak pada keselamatan stasiun. Untuk keputusan lain, solusi multilateral lebih disukai, tetapi jika tidak ada konsensus yang bisa dicapai, Amerika Serikat tetap memiliki keputusan akhir. Stasiun itu dibagi dalam bagian Rusia dan Amerika, dan jika Rusia tidak setuju dengan keputusan Amerika itu hanya akan berlaku untuk setengah Amerika. Demikian pula, perjanjian sebelumnya di ISS menyatakan bahwa semua astronot di stasiun itu akan jatuh di bawah hukum Amerika. Perjanjian baru menyatakan bahwa astronot akan jatuh di bawah yurisdiksi negara mereka sendiri, kecuali mereka membahayakan astronot atau material yang rusak dari negara lain (Yakovenko, 1999). Ketika Space Station Freedom akan menjadi perpanjangan dari kedaulatan Amerika dan hegemoninya, Stasiun Luar Angkasa Internasional telah menjadi urusan internasional (Moenter, 1999).

Tetapi partisipasi Rusia memiliki kekurangan. Masalah terbesar adalah ketidakstabilan sistem politik dan ekonomi Rusia. Meskipun program itu mungkin membantu 
menstabilkan berbagai hal, itu jelas hanya memainkan peran kecil di teater domestik Rusia. ISS tidak dapat menghentikan Rusia yang gagal dan jika itu terjadi, kemungkinan akan gagal juga. Krisis keuangan Rusia pada tahun 1999 menyebabkan program luar angkasa Rusia menyatakan kebangkrutan. NASA harus turun tangan dan secara drastis meningkatkan pendanaan untuk proyek sebelumnya menjadi 600 juta dolar untuk memungkinkan Rusia melanjutkan program, meskipun panduan NASA mengurangi transfer dana sebanyak mungkin (Moenter, 1999). NASA juga memulai pengembangan pengganti salah satu komponen penting yang seharusnya diproduksi Rusia. Ini terbukti tidak perlu, meskipun Rusia masih dua tahun terlambat dengan bagian proyek ini (Sadeh, 2004).

Agar Rusia bergabung dengan ISS, Amerika harus berkompromi dengan harapan awal mereka terhadap proyek tersebut. Rusia diberi lebih banyak wewenang dan diberi tanggung jawab untuk membangun dan memelihara bagian-bagian penting misi dari stasiun, dan bahwa terlepas dari fakta bahwa partisipasi Rusia membawa risiko. NASA harus meninggalkan beberapa pedoman tentang kerja sama yang telah dijaga selama Perang Dingin, termasuk transfer uang besar untuk membantu badan antariksa Rusia yang gagal. AS jelas bersedia bekerja jauh untuk bekerja sama dengan mantan lawannya untuk meningkatkan stabilitas global.

\section{Komitmen Kerja Sama Rusia dan Amerika Serikat}

Selain reputasi Rusia dan ISS di bidang luar angkasa, adanya komitmen kedua negara yaitu Rusia dan Amerika Serikat juga menentukan kekuatan kerja sama. Komitmen awal antara dua negara untuk melakukan kerja sama luar angkasa tidak terlepas dari reputasi kedua negara di bidang tersebut. Baik Rusia maupun Amerika Serikat memiliki reputasi yang baik di bidang luar angkasa. Sehingga, komitmen antara kedua negara melakukan kerja sama tentu akan memperkuat kerja sama itu sendiri.

Komitmen kerja sama Rusia dengan Amerika Serikat ini semakin kuat pasca peristiwa 11 September. Setelah pertemuan antara Presiden Bush dan Presiden Vladimir Putin pada 16 Juni 2001, Presiden Vladimir Putin menyatakan bahwa Rusia dan Amerika Serikat bukan musuh dan tidak saling mengancam. Rusia dan Amerika Serikat dapat menjadi aliansi yang kuat. Lebih lanjut, Presiden Bush menambahkan bahwa Rusia dapat menjadi teman yang kuat bagi Amerika Serikat. Kedua negara sepakat ingin meninggalkan hubungan saat Perang Dingin dan membangun hubungan kerja sama yang lebih kuat dan harmonis (Gladkyy, 2003).Setelah kejadian 9/11, hubungan Amerika Serikat dan Rusia berfokus pada 
terorisme internasional dan perang di Afghanistan. Amerika memiliki ketertarikan terhadap Rusia khususnya dalam bidang akses militer dan pengetahuan Rusia terhadap Afganistan. Hal ini juga dideklarasikan oleh Bush, sebagai Presiden Amerika Serikat kepada Kongres di tanggal 20 September 2011 bahwa Amerika Serikt akan berupaya bekerja sama dalam penanganan terorisme di mulai dari Al-Qaeda.

Pada bidang kerja sama luar angkasa, Rusia dan Amerika Serikat juga menunjukkan komitmen. Kedua negara memandang bahwa kerja sama antara keduanya dapat memberikan keuntungan bagi masing-masing pihak. Amerika Serikat menyatakan "together let us explore the stars". Amerika Serikat juga lebih memilih melakukan kerja sama daripada kompetisi dalam isu luar angkasa. Pada akhirnya, Rusia dan Amerika Serikat melakukan kerja sama dalam bidang luar angkasa termasuk perkembangan, perencanaan, dan ekplorasi internasional (Logsdon \& Williamson, 1995). Hal ini menunjukkan bahwa Amerika Serikat dan Rusia memiliki komitmen untuk melakukan kerja sama yang juga berdasarkan reputasi masingmasing negara di bidang tersebut yang telah dijelaskan pada sub-bab sebelumnya.

\section{SIMPULAN}

Dari uraian tersebut di atas, tulisan ini sudah menunjukkan bahwa alasan dibalik sikap Rusia yang pada akhirnya mau melakukan kerja sama di bidang pengembangan angkasa luar dengan Amerika Serikat melalui proyek ISS cenderung sangat praktikal. ISS adalah contoh kolaborasi yang sukses antara mantan pesaing yang masih tidak yakin tentang hubungan mereka. Amerika Serikat berkeinginan untuk berkompromi mengenai harapan dan panduannya untuk memasukkan Rusia ke dalam proyek, untuk memastikan hubungan bilateral yang lebih baik dan untuk meningkatkan stabilitas global setelah berakhirnya Perang Dingin. Namun pada akhirnya Amerika Serikat mau mengkompromikan kepentingannya ketika Rusia tengah mengalami krisis pendanaan. Hal ini dilakukan Amerika Serikat dengan harapan Rusia akan tetap melakukan kerja sama dengannya dan tetap melanjutkan proyek stasiun luar angkasa sampai di masa depan.

Hal yang juga membuat Rusia menjadi yakin untuk melakukan kerja sama dengan Amerika Serikat di luar angkasa adalah kebutuhan Rusia akan tempat untuk menaungkan ilmuwan-ilmuwannya yang tidak dapat mereka fasilitasi sendiri dikarenakan adanya perjanjian tertentu terkait negara-negara mantan sekutu Uni Soviet. Meskipun pada akhirnya Rusia tidak sepenuhnya menginginkan transfer teknologi yang kentara terhadap Amerika Serikat dikarenakan banyaknya teknologi militer sensitif milik Rusia yang sangat diinginkan 
oleh Amerika Serikat, namun Rusia mencoba membangun kepercayaan dengan Amerika Serikat dengan meminta Amerika Serikat untuk tidak terlalu menekan mereka dalam bidang tersebut. Rusia juga mencari keuntungan dalam kerja sama ini untuk membiayai proyek sains luar angkasanya dan membuat NASA memberikan anggaran lebih kepada ISS agar Rusia bisa memotong dananya yang sudah dianggarkan untuk ISS guna dipakai untuk keperluan pendanaan proyek luar angkasa domestiknya.

Alasan lebih lanjut untuk kerja sama adalah keinginan untuk menjaga stabilitas tatanan global, seperti dengan ISS dan undang-undang luar angkasa. Apabila dua negara adidaya seperti Amerika Serikat dan Rusia tetap bertikai di ruang angkasa, maka akan terjadilah peperangan kembali seperti pada Space Race yang terjadi antara Amerika Serikat dan Uni Soviet di masa lampau. Space Race pada akhirnya menimbulkan kerugian bagi kedua belah pihak dan mengancam kepentingan masing-masing negara. Sesama rival tidak dapat bekerja sama jika kepentingan militer strategis bertabrakan dan iklim non-kerjasama dapat membuat kerjasama sulit meskipun alasan yang baik. Oleh sebab itu Rusia tetap menjaga kepentingan militernya di luar angkasa tidak berseberangan dengan Amerika Serikat seperti halnya keadaan militer mereka di muka bumi.

\section{DAFTAR PUSTAKA}

Activity, R. F. (1993, October). Law of the Russian Federation on Space Activity. Retrieved May 24, 2018

Brooks, L. F. (2009). A Vision for U.S.-Russian Cooperation on Nuclear Security. Issues in Science and Technology, 26(1), 25-28.

Everett, D. (2002). Classical Geopolitics in the Space Age. Astropolitik.

Fearon, J. D. (1994). Domestic Political Audiences and the Escalation of International Disputes. American Political Science Review.

Gladkyy, O. (2003). American Foreign Policy and U.S. Relations with Russia and China after 11 September. World Affairs, 166(1), 3-23.

Hall, T., \& Yarhi, M. K. (2012). The Personal Touch: Leaders Impression, Costly Signaling. and Assessments of Sincerity in International Affairs. International Studies Quarterly, 56(3), 560-573.

Katz, M. N. (2014). Can Russian-US Relations Improve? Strategic Studies Quarterly, 8(2), 129-141.

Kreps, D. (1990). Corporate Culture and Economic Theory. New York: Cambridge University Press.

Launius, R. D. (2009). United States Space Cooperation and Competition: Historical Reflections. Astropolitics, 7(2), 89-100.

Logsdon, J. M. (1991). Together in Orbit: The Origins of International Participation in Space Station Freedom. Washington: NASA Contractor Report 4237.

Logsdon, J. M., \& Williamson, R. A. (1995). U.S.-Russian Cooperation in Space: A Good Bet. Issues in Science and Technology, 11(4), 39-45. 
Luongo, K. N. (2001). Improving U.S.-Russian Nuclear Cooperation. Issues in Science and Technology, 18(1), 85-91.

Lynn, F. H., \& Gibbs, G. (2003). Re-negotiation of the International Space Station Agreements. Acta Astronautica.

Mercer, J. (1996). Reputation and International Politics. Ithaca, NY: Cornell University Press.

Moenter, R. (1999). The International Space Station: Legal Framework and Current Status. Journal of Air Law and Commerce.

Oliker, O., Crane, K., Schwartz, L. H., \& Yusupov, C. (2009). Russian Foreign Policy. California: RAND Corporation.

Sadeh, E. (2004). Technical, Organizational and Political Dynamics of the International Space Station Program. Space Policy, 185-186.

Sadeh, E., \& Lester, J. P. (1996). Modelling International Cooperation of Space Exploration. Space Policy .

Savelyev, A. G. (2004). Prospects for US-Russian Cooperation in Ballistic Missile Defense and Outer Space Activities. Journal of Slavic Military Studies, 17(1), 99-109.

Shaffer, M., \& Shaffer, L. R. (1980). The Politics of International Cooperation: A Comparison of U.S. Experience in Space and Security. Denver: University of Denver.

Whiting, S. N. (2003). Space and Diplomacy: A New Tool for Leverage. Astropolitics.

Wilkening, D. A. (2012). Cooperating With Russia on Missile Defense: A New Proposal. Arms Control Today, 42(2), 8-13.

Yakovenko, A. V. (1999). The Intergovernmental Agreement on the International Space Station. Space Policy.

Yeltsin, B. (1992). Decree Establishing the Russian Space Agency. Moscow. 